\title{
Rights for Development: An analysis of the strengths and weaknesses of a human rights approach to overcoming food insecurity and gender discrimination ${ }^{1}$
}

\author{
Guisela Camacho-Mejía² \\ Pontificia Universidad Católica del Perú \\ guiselacamacho@gmail.com \\ Código ORCID: https://orcid.org/0000-0001-8459-4018
}

Abstract:

This article explores the advantages and disadvantages of using a human rights-based approach to addressing two persistent development challenges: food insecurity and gender discrimination. As an exploratory paper, it does not propose a thesis but rather defines key concepts and legal norms of the human rights-based approach (HRBA), as well as its implications for food security and gender discrimination. Despite its exploratory nature, the paper remains a fair starting point for a more critical examination of the role played by human rights in the development field. This paper is divided into four sections. The first section lays forth a theoretical framework for HRBA, emphasizing its key features and operational principles. The second section explores the benefits and drawbacks of using HRBA to achieve development goals. The third section proposes some guidelines to achieve a world without hunger and food insecurity. The fourth section discusses how HRBA might contribute to overcoming gender discrimination. Finally, I outline the main takeaways.

Keywords: Human rights approach to development, gender discrimination, food security and litigation.

\section{Resumen:}

Este articulo explora las ventajas y desventajas de emplear un enfoque basado en derechos para abordar dos objetivos de desarrollo: seguridad alimentaria e igualdad de género. Este es un artículo exploratorio y, como tal, no desarrolla una tesis, sino que define conceptos e identifica normas claves del enfoque basado en derechos (EBDH). Teniendo en cuenta esta limitación, este articulo ofrece un buen punto de partida para un análisis más crítico del rol que desempeñan los derechos humanos en el campo de desarrollo. Este articulo tiene cuatro secciones. La primera sección establece un marco teórico para el $\mathrm{EBDH}$, con enfasis en sus características clave y principios operativos. La segunda sección explora los beneficios y los inconvenientes de utilizar un EBDH para lograr los objetivos de desarrollo sostenible. La tercera sección elabora el derecho a la alimentación y lo vincula con el ODS 2. La cuarta sección analiza cómo un EBDH podría contribuir a superar la discriminación de género y alcanzar ODS 5. Finalmente, formulo las principales conclusiones.

Palabras clave: enfoque basado en derechos humanos, seguridad alimentaria, igualdad de género, litigación internacional.

1 Note and disclaimer:

This paper is based on two course essays written by the author for the course "HUMR5702: Human Rights and Sustainable Development: Interdisciplinary Perspectives on Theory and Practices." Therefore, it grounds on the literature covered in this course, which was taught during the winter of 2018 at the Faculty of Law, University of Oslo.

${ }^{2}$ Bachiller en Derecho por la Pontifica Universidad Católica del Perú y Magister (M. Phil.) en Derechos Humanos por la Universidad de Oslo. 


\section{Introduction}

The concept of development and the suggested means for achieving it have shifted considerably since development theory appeared after World War II (Bull, 2006). In the early years, the Modernization School equated development with economic growth, industrialization and massive capital investments in developing countries. Later, the Dependency School claimed that development was not possible without the establishment of a New Economic Order, one that addresses the unfair trade relationships between the centre (western industrialized countries) and the periphery (countries that were previously colonies).

In recent years, a new concept has assumed a central role in the theory and practice of development, the one of human rights (Gready and Ensor, 2005). This approach has as main feature the reading of the outcomes and process of development through international human rights instruments and standards (Sano, 2007). Currently, the scope of the human rights-based approach (HRBA) is wide and embraces the activities of development organizations at the national and international levels.

Particularly, the United Nations (UN) Agencies have adopted the HRBA as a common framework for development cooperation and programming ${ }^{4}$. As a result, all UN development cooperation programs should be read through the lens of the HRBA. Currently, the UN 2030 Agenda for Sustainable Development is the most ambitious initiative for international development. This universal agenda consists of 17 goals and 169 targets to be reached by 2030 in areas that are critical to humanity (UN General Assembly, 2015). Among these are Sustainable Development Goal (SDG) 2, which aims to eradicate hunger and improve food security, and SDG 5, which purposes to achieve gender equality, end gender discrimination, and empower women and girls.

In such a context, this paper examines how a HRBA may contribute to the implementation of SDG 2 and SDG 5. Regarding SDG 2, this paper aims to provide guidelines for the implementation of its five targets. To do so, I rely on sources of international "hard law" and "soft law" as well as resources and tools from development theory. Regarding SDG 5, this paper discusses how HRBA may help to overcome gender discrimination. To do so, I look at two cases of strategic litigation that had a positive impact on gender equality.

Keeping these objectives in mind, this paper is divided into four sections. The first section lays out key features and operational principles of HRBA and explores the benefits and drawbacks of using HRBA to achieve development goals. The second section proposes some guidelines to achieve a world without hunger and food insecurity. The third section discusses how HRBA might contribute to overcoming gender discrimination. Finally, I outline the main takeaways.

\section{SECTION I: A Human Rights-Based Approach to Development}

\subsection{What is a Human Rights-Based Approach to Development?}

According to the High Commissioner for Human Rights, HRBA is:

"(...) a conceptual framework for the process of human development that is normatively based on international human rights standards and operationally directed to promoting and protecting human rights (...)" (Office of the United Nations High Commissioner For Human Rights, 2008).

Thus, HRBA has two main features (Jonsson, 2005). First, the main objective of development is the direct realization of one or several human rights as laid down in the international human rights instruments; and, second, the process of development should fulfil human rights standards and principles. The understanding of development outcomes and processes through international human rights principles requires the building of a dualistic structure of duty-bearers and rights- 
holders among development stakeholders (Sano, 2007). Therefore, a third main feature of HRBA is that it requires identifying the entitlements of the rights-holders and the obligations of the dutybearers (United Nations Development Group, 2003) ${ }^{5}$.

Using HRBA to development requires the re-definition of the concept of development itself. In this vein, Arjun Sengupta, former Independent Expert on the Right to Development, has redefined development as "a progressive and phased realization of all the recognized human rights (...) as well as a process of economic growth consistent with human rights standards" (Sengupta, 2010, 20). Based on this definition, it is possible to infer some elements for the operationalization of HRBA:

- When confronted with a development challenge, it is important to recognize the main human rights that lie beneath it. Therefore, the first step is to make a list of rights that are either being violated or are at risk of being violated (Jonsson, 2005, 53). The Universal Declaration of Human Rights, the International Covenant on Economic, Social and Cultural Rights and the International Covenant on Civil and Political Rights are key instruments in this regard.

- Second, grounding on the guidelines developed by international human rights bodies and mechanisms, each right must be linked to clear and specific entitlements (claims) and obligations. Moreover, since human rights bring a dual structure of rights and obligations, it turns critical to identify who in the development field is a right-holder and who is a duty bearer (United Nations Development Group, 2003).

- Finally, general principles of human rights should be used as benchmarks for all the efforts of development, including the process of economic growth. The next section outlines the fundamental principles that guide the process and outcomes of development.

\subsection{Which are the core principles of a Human Rights-Based Approach?}

According to Kirkemann and Sano (2010), despite the differences between how organizations conceptualize HRBA, it is possible to discern common constituent elements or principles of $\mathrm{HRBA}^{6}$ :

a. Indivisibility and interdependence: This principle states that the full enjoyment of civil and political rights is impossible without the enjoyment of economic, social and cultural rights (Gready and Ensor, 2005). From a HRBA, this principle demands that development activities targeted at fulfilling one human right should not be undertaken at the expense of another (Kirkemann and Sano, 2010).

b. Equality and non-discrimination: This principle is summed up with the phrase "no one left behind." It forbids making distinctions between individuals based on unreasonable criteria. From a HRBA, this principle requires special protection to vulnerable groups of the population, such as women, elderly people, and indigenous peoples and in general, groups that have a disadvantaged social position (Kirkemann and Sano, 2010).

c. Accountability: This principle grounds on the dual structure of right-holder and duty-bearer. On the one hand, it changes the status of marginalized groups who are no longer a passive object of development, but rather valid claimants of legal obligations (Sengupta, 2020). On the other hand, it broadens and diversifies the areas of accountability (for example, extraterritorial obligations of States) and the accountable actors (for example, international organizations, private corporations, and aid donors) (Sano, 2007).

d. Participation: This principle is based on the premise that rights holders are genuine actors in the development process, and hence have the right to make effective decisions about matters affecting their own lives. From a HRBA, it encourages vulnerable people and their associations to participate in all the stages of programming (Sano, 2007). 
The HRBA requires that these principles guide all stages of development programs, from conception to evaluation. Thus, human rights are utilized as a guide to establishing development goals and a touchstone to assess development outcomes.

\subsection{Strengths of a Human Rights-Based Approach}

In comparison to development approaches, the HRBA has four distinct strengths or advantages. First, HRBA has created a shared methodological framework that is considered legitimate at the local, national and international levels (Sengupta, 2010). As previously indicated, HRBA is founded on provisions of international human rights law. Currently, every country is constrained - to varying degrees - by these instruments. This has resulted in the creation of a common normative and institutional framework that legitimizes development activities and facilitates coordination among actors at various levels (Goonesekere, 2009).

Second, the HRBA has fundamentally altered the foundations of development cooperation and development aid. According to the UN Charter, all States are required to contribute - jointly or separately - to achieving universal social and economic development ${ }^{7}$. Therefore, development aid ceases to be a matter of charity and becomes one of entitlements and legal obligations. Furthermore, the rich and extensive work made by treaty body-based and UN Charter-based human rights procedures adds to broadening and clarifying the scope and content of development goals.

Thirdly, the HRBA prioritizes vulnerable rights holders and empowers them as legitimate development agents capable of fulfilling their own needs and determining their own development goals. This implies that the primary actors in development are not multilateral or bilateral donors, but rather the "target groups" of development aid. As a result, development programs should emphasize these groups and their capacities to participate in decision-making processes.

Fourth, the HRBA provides the use of legal remedies when the goals of development are not met or when the processes by which they are met violates human rights standards ${ }^{8}$. These legal remedies are available at two levels: national and international. At the national level, domestic NGOs and civil society organizations use public interest litigation to hold national authorities accountable for human rights violations. At the international level, individuals and collectives use international human rights courts and committees to put pressure on national authorities when domestic remedies have not been effective to correct human rights breaches.

\subsection{Weaknesses of a Human Rights-Based Approach}

The strengths of the HRBA described above comprise, at the same time, some weaknesses. This section examines four of them. First, the common methodological framework created by the HRBA may not be equally legitimate at different levels. For example, at the national level, the principles and standards of international human rights law have been contested by different countries such as the United States (regarding the prohibition of torture during the George W. Bush administration) (Risse et al., 2013) and China (with the "China's preferred approach to human rights") (Jetschke and Liese, 2013).

Second, the HRBA fails to address development challenges in areas where governments have limited statehood or in States with imperfect democracies. Since the HRBA rests on the basic idea that States are the main duty-holders, it presupposes the existence of a sufficiently wellfunctioning State against which rights-holders can assert their claims (Broberg and Sano 2017). However, most of the developing countries -which are the main targets of development aid-, have weak democratic institutions, inefficient judicial systems and the State lacks the monopoly of power. 
Third, while the core principle of participation should govern the entire development process, the actors engaging in the design of HRBA programs are not always the beneficiaries. As Sano points out, the HRBA has underestimated the challenges associated with the genuine participation of marginalized groups $(2007,67)$. The participation of vulnerable groups in development programs should not be taken for granted but should be actively sought out and promoted. Otherwise, the HRBA may be used to maintain the status quo by privileged actors.

Fourth, the effectiveness of using legal remedies to achieve development goals is debatable. On the one hand, legal mobilization and successful litigation are only possible if a) the right's holders are conscious of their rights and $b$ ) the targeted State counts with an independent judicial system (Epp, 1998). Without these prerequisites, structural reforms through litigation are improbable. On the other hand, the effectiveness of litigation is contingent upon the rights holders' capacity to pursue their claims until getting a definitive legal response. Due to these material circumstances, legal remedies are not appropriate for all rights holders.

\subsection{Conclusion}

This section examined the main concepts, traits and principles of the HRBA. Later it discussed the advantages and disadvantages of using such an approach in the development field. The primary takeaway is that the HRBA has redefined the processes and outcomes of development. It aims to participatory processes and human-centred outcomes. Such objectives, however, are dependent on strong democratic institutions, equitable access to resources, and social recognition, none of which are directly addressed by the HRBA.

\section{SECTION II: Achieving a world without hunger and malnutrition from a Human Rights- Based Approach}

This section addresses the potential contributions of the HRBA for the implementation of SDG 2. It first explains the normative scope of the right to food before formulating some guidelines for the implementation of SDG 2. Finally, it examines some of the benefits and drawbacks of using HRBA to achieve SDG 2.

\subsection{The Sustainable Development Goal 2 and the right to adequate food}

The SDG 2 aims to end hunger, achieve food security, improve nutrition, and promote sustainable agriculture. It is operationalized through five targets. The first two targets seek to free the world of hunger and malnutrition, while the remaining three targets focus on the means to achieve the first two outcomes. In particular, the third target seeks to double the agricultural productivity and to increase the incomes of small-scale food producers; the fourth target aims to ensure sustainable food production systems that guarantee production and adaptation to climate change; and the fifth target purposes to maintain the genetic diversity of seed, plants and animals.

Following the above-mentioned elements for the operationalization of HRBA (United Nations Development Group, 2003; Jonsson, 2005), SDG 2 can be primarily translated as the human right to adequate food ${ }^{9}$. This right is recognized in international human rights instruments, such as the Universal Declaration of Human Rights (article 25), the International Covenant of Economic, Social and Cultural Rights (article 11) and the Protocol of San Salvador (article 12) ${ }^{10}$. According to the General Comment $N^{\circ} 12$ (1999) elaborated by the Committee on Economic, Social and Cultural Rights, the basic content of the right to adequate food consists on (G.C. No 12 , par. 8):

"The availability of food in a quantity and quality sufficient to satisfy the dietary needs of individuals, free from adverse substances, and acceptable within a given culture; 
The accessibility of such food in ways that are sustainable and that do not interfere with the enjoyment of other human rights".

Therefore, the right to adequate food cannot be reduced to ensuring a minimum number of calories (right to be free of hunger) but it needs to be read from a maximalist approach (G.C. $\mathrm{N}^{\circ} 12$, par. 6 ). This means that individuals should have access at all times to food that fulfils requirements of adequacy, safety, cultural acceptability and sustainability. According to G.C. No 12, sufficiency requires that the diary diet contain the necessary combination of nutritious products to promote healthy development throughout the life cycle (G.C. $\mathrm{N}^{\circ} 12$, par. 9). Safety requires avoiding the contamination of food products due to human causes, such as adulteration, poor environmental hygiene, and incorrect handling during distribution (G.C. $N^{\circ} 12$, par. 10). Cultural acceptability emphasizes the importance of preserving the social values and cosmologies associated with food and food consumption (G.C. $\mathrm{N}^{\circ} 12$, par. 11). Finally, sustainability requires that the production, processing, distribution, and consumption of food adhere to standards of sustainable management and use of natural resources that ensure future generations will have access to adequate food (G.C. N ${ }^{\circ} 12$, par. 7 and par. 25).

Furthermore, like other human rights, the right to adequate food presumes a dualistic structure of rights-holders and duty-bearers. The rights-holders are the 815 million undernourished people (FAO, SOFI, 2017). The duty-bearers are mainly the States; however, all members of society have responsibilities in the realization of this right (G.C. $\mathrm{N}^{\circ} 12$, par. 20). Thus, civil society organizations at the local, national and international levels have the obligation of monitoring state policies and practices. Moreover, the private business sector must, at least, not negatively interfere with the capacities of the people to satisfy the nutritional necessities of their families (G.C. $N^{\circ} 12$, par. 20).

Finally, the right to food imposes three obligations to States (G.C. $N^{\circ} 12$, par. 15). First, States must not adopt measures that result in hindering the availability, access or adequate biological use of food (obligation to respect) (G.C. No12, par. 15; UN.Doc.A/68/288 par. 11). Second, states must adopt appropriate measures to ensure that companies and, in general, individuals, do not deprive people of access to adequate food (G.C. N²12, par. 15; UN.Doc.E/CN.4/2006/44; UN.Doc.A/68/288 par.11) (obligation to protect). Finally, when an individual or a group is unable, for reasons beyond their control, to enjoy the right to adequate food by the means at their disposal, States should realize that right directly (obligation to fulfil)(G.C. Nº12, par.15; UN.Doc.E/CN.4/2006/44; UN.Doc.A/68/288 par. 11).

\subsection{Implementing Sustainable Development Goal 2 using a Human Rights-Based Approach}

This section proposes broad guidelines for implementing SDG 2 in accordance with the aforementioned HRBA principles. Given that SDG 2 is translated into the human right to adequate food, I sustain the proposal using the normative framework developed by the Committee on Economic, Social and Cultural Rights and the Special Rapporteur on the Right to Food.

- Indivisibility and interdependence: The implementation of one SDG 2 target cannot have a negative impact on other targets or human rights. For instance, the objective of ending hunger (target 1) cannot be achieved through unsustainable food production systems (target 4). This is the case in Mexico, where the use of transgenic maize endangers the diversity of native maize landraces while making little contribution to food security. (UN.Doc.A/HRC/19/59 Add.2, par. 52-55).

- Equality and non-discrimination: Although SDG 2 has universal scope, it is well known that specific groups of the population are most affected by hunger and malnutrition. According to $\mathrm{FAO}$, these groups are food producers, pregnant women, children under 5 years old, elderly people and indigenous people (FAO, SOFI, 2017). These groups need to be prioritized in food security policies and programs to subvert systematic discrimination. For instance, in 
Peru, the National School Feeding Program Qali Warma provides food items and services to children enrolled in public elementary and primary schools. This service is bolstered in the case of children from indigenous Peruvian Amazon populations, who receive food services up to secondary level ${ }^{11}$.

- Participation: The implementation of SDG 2 should incorporate as main actors those groups and individuals who suffer from hunger or malnutrition, as well as their representative organizations. In particular, local social organizations and national NGOs should be involved in the formulation of national strategies on food security and nutrition (G.C. $N^{\circ} 12$, par. 2324). Effective participation is essential for addressing the root causes of hunger and tailoring programs that respond to the local context.

- Accountability: Generally, those with the ability to influence other actors' availability or access to adequate food should be held accountable in cases of human rights violations. As a result, any individual or group who is subjected to a violation of the right to adequate food should be able to seek effective judicial or administrative remedies and reparations (G.C. $N^{\circ} 12$, par. 32-35). A good example of the power of legal mobilization is the well-known Peoples' Union for Civil Liberties case. In this case, the Supreme Indian Court ordered a midday meal for schoolchildren, the distribution of subsided grain to people suffering from poverty, sickness and disability, as well as free grain for the elderly (Gonsalves, 2005, 220).

\subsection{Advantages and disadvantages of implementing Sustainable Development Goal 2 through a Human Rights-Based Approach}

This section discusses the advantages and disadvantages of implementing SDG 2 through HRBA. Among the advantages are:

- Normative precision: The rich interpretative work done by the Committee on Economic, Social, and Cultural Rights and the Special Rapporteur on the right to food has clarified the normative content and scope of the right to food. This feature contributes to creating an epistemic community that shares common understandings, common language, common technical language, and in general, a common set of causal mechanisms and solutions to hunger and malnutrition (Sano, 2007, 68-69).

- Legal mobilization: The translation of SDG 2 into the right to food allows demanding food security policies and programs targeted at groups more vulnerable to hunger and malnutrition in domestic courts. As a result, claims for food security become a constitutional matter that can be enforced by judicial authorities regardless of governmental will. The innovative case law developed by the Colombian Constitutional Court and the South-African Constitutional Court exemplifies the benefits of framing food claims into a human rights framework (Gauri and Glappen, 2012, 17).

Among the disadvantages are:

- Restricted scope: Some targets of SDG 2 -as the fourth and fifth targets that aim to ensure sustainable food production systems and maintain the genetic diversity of seeds, plants and animals- may not be effectively addressed from an adversarial structure of duty-bearer/rightsholder. Since these targets require mainly technical and technological capacities; they might be better addressed through a logic of constructive cooperation among all actors of the food system (Gready and Ensor, 2005, 38-39).

- Uniformization of development proposals: The concept of food security and the right to food are not the only approaches to achieving SDG 2. Via Campesina and the International Peasant Movement, for example, have proposed the concept of Food Sovereignty (European 
Coordination Via Campesina, 2018). In general, Food Sovereignty commits to a constructive dialogue between food producers and food consumers to create a sustainable food system of and for the people. These voices, however, have gone unheard in the implementation of SDG 2 and the binding instruments that enshrine the right to food.

\subsection{Conclusion}

This section explored the content of the right to food and proposed general guidelines for the implementation of SDG 2. Although HRBA gives clear guidance about where to go (goals), it is less clear regarding how to get there (implementation). It seems that the adversarial format offered by human rights mechanisms might not be adequate to address development challenges that require coordination of actors with widely disparate interests, power and resources.

\section{SECTION III: A Human Rights-Based Approach to Gender Discrimination}

As previously stated, the principle of equality and non-discrimination is one of the fundamental principles of human rights. This principle states that all human beings are born free and equal in dignity and rights (UDHR art.1). As a result, it is prohibited to make distinctions based on unjustified criteria such as gender and sex (UDHR art.2). Gender discrimination refers to "any distinction, exclusion or restriction made on the basis of sex which has the effect or purpose of impairing or nullifying the recognition, enjoyment or exercise by women (...) of human rights and fundamental freedoms in the political, economic, social, cultural, civil (...) fields" (CEDAW art.1). Through this Convention, adopted in $1979^{12}$, the States Parties condemned any kind of discrimination against women and compromised to take all the appropriate means to eliminate $\mathrm{it}^{13}$.

Despite this normative compromise, the root causes of gender discrimination still curtail women's rights in public and private. In the private sphere, women are still subjected to domestic violence and harmful practices such as child marriage and female genital mutilation. Furthermore, women do more unpaid domestic work than men, as evidenced by the COVID 19 crisis. In the public sphere, women continue to have limited political participation. As a result, women hold only 23.7 percent of parliamentary seats and less than one-third of senior and middle management positions (UNWOMEN, 2017).

Thus, gender discrimination represents a current challenge that must be faced to achieve peace and development (UN General Assembly, 2015). In the Sustainable Development Goals, gender equality is addressed in SDG 5 and operationalized in 6 targets. The first three goals are to eliminate all forms of discrimination, violence, and harmful practices against women. The remaining three are concerned with the role of women in public life. It recognizes the burden that women bear as a result of domestic work, encourages women's participation in decision-making and political life, and protects their reproductive rights.

In this context, this section explores how the HRBA can contribute to achieving SDG 5 and its targets. First, it develops four contributions of HRBA to gender equality and later it deepens on litigation as a way to denounce gender discrimination.

\subsection{Empowerment of women as rights-holders}

A HRBA empowers women on two fronts. At an internal level, it enables a shift in women's identities as empowered actors with rights that must be respected, protected and guaranteed by the State and private actors. A HRBA allows the self-recognition of women as subjects of entitlements who can decide freely on matters related to their life. At an external level, a human rights approach revalorizes women's role in society and their contribution to welfare outcomes (Goonesekere, 1998). Thus, women transition from being a passive object of law to being a subject of law with legal rights and entitlements. 
Considering women as rights holders has also facilitated the formation and strengthening of civil society organizations and non-governmental organizations dedicated to the advancement of women's rights and gender equality. These institutions are indispensable for effective advocacy of women rights at national and international levels (Sano, 2007, 70-71). At the same time, recognizing women as rights holders enables and encourages jurisdictional authorities to accept their claims as valid and to rule in their favour.

\subsection{Accountability of the duty-bearers}

Following Goonesekere (1998), an HRBA "promises the State's engagement in a way that other approaches to claims cannot." A HRBA does bolster States' accountability, as development goals have become legally enforceable obligations. Additionally, as demonstrated in the preceding section, it provides a working normative framework that develops the scope of the State's obligations. For example, in its General Recommendation 28, the Committee on the Elimination of Discrimination Against Women clarified States' obligations regarding women's right to non-discrimination.

According to this instrument, States must refrain from enacting laws, policies, regulations, programs, and administrative procedures that discriminate against women (obligation to respect) (G.R. No 28, par. 9). Moreover, States must safeguard women against discrimination by private actors and take action to eliminate all practices that perpetuate the superiority/inferiority of either sex (obligation to protect) (G.R. No 28, par.9). Furthermore, States must also take appropriate steps to ensure gender equality, such as measures of a legislative, administrative or policy nature (obligation to fulfil) (G.R. No 28, par. 9).

\subsection{Reporting and monitoring of international and national institutions/organs}

A HRBA also provides an institutional framework for monitoring the implementation of gender equality policies, programs, and legal reforms. The reporting/monitoring mechanisms are critical to ensuring the effective implementation of women's rights because they hold States accountable, facilitate policy and legal reforms and ensure law enforcement in sensitive areas (Goonesekere, $2007,59)$. Although the instruments developed by these mechanisms are not legally binding, they enjoy social legitimacy and serve as a channel through which national NGOs and individuals can express their concerns to the international community.

In the universal system, the Committee on the Elimination of All Forms of Discrimination against Women is the organ in charge of monitoring the States' progress in the implementation of women's right to non-discrimination ${ }^{14}$. To achieve this goal, CEDAW has created a reporting system. States must report to the Committee on any legislative, judicial, or administrative measures taken to combat gender discrimination (CEDAW G.R. No 1 and No 2). The Committee considers these reports in a constructive dialogue between representatives from the State, Committee members, and national NGOs. As a result, CEDAW submits its concluding observations, in which it recognizes the positive aspects of the States' actions as well as the main areas of concern and recommendations.

In the regional system, the Protocol to the African Charter on Human and Peoples' Rights on the Rights of Women in Africa ${ }^{15}$ establishes that States shall submit periodic reports to the African Commission on Human and Peoples' Rights indicating the measures taken towards the realization of women's right to non-discrimination (Art. 26 Maputo Protocol). Likewise, the Inter-American Convention on the Prevention, Punishment and Eradication of Violence against Women ${ }^{16}$ orders that States shall include information on the measures adopted to implement their treaty's obligations in their national reports (Art. 10 Convention of Belem do Para). Finally, the Council of Europe Convention on Preventing and Combating Violence against Women and Domestic Violence ${ }^{17}$ has a special monitoring body (Art. 1.2. Istanbul Convention), the Group of Experts on Action against Violence against Women and Domestic Violence, which oversees the implementation of conventional rights. 


\subsection{Accessing to legal remedies}

A HRBA provides effective remedies in the event that private actors or the State itself undermine gender equality or breach women's right to non-discrimination. States compromised through the above-mentioned treaties to ensure that women have access to courts or other bodies that provide timely, appropriate, and effective remedies. These remedies may be judicial or quasi-judicial in nature, and they may exist at both the national and international levels.

The prohibition of women's right to non-discrimination at the national level may be included in constitutional, civil, family, criminal, administrative, social, or labour law (UN.Doc.CEDAW/C/ $\mathrm{GC} / 33$ ). As a result, an appropriate and effective remedy can be obtained through various thematic courts and administrative quasi-judicial bodies, depending on the national institutions and judicial arrangements. If women are unable to obtain effective remedies on a domestic level, they can present their claims in an international forum. There are two international mechanisms for obtaining reparation. The first is the jurisdictional procedure of the regional courts of human rights, and the second is the quasi-jurisdictional procedure of the universal system via individual communications.

In the regional system, the Inter-American, European and African Courts of Human Rights are in charge of deciding whether or not there has been a violation of the women's right to nondiscrimination. Their decisions are significant because they have a mandatory/binding nature, which means that States Parties must execute and comply with the Court's decision. Furthermore, in the universal system, the treaty-body organs are in charge of handling individual complaints. The CEDAW jurisprudence is particularly pertinent to gender discrimination. This organ can receive communications submitted by or on behalf of individuals or groups of individuals who claim to be victims of violations of any of the Convention's rights.

\subsection{The contribution of litigation to achieve gender equality: Two case-studies}

Successful litigation can help to advance gender equality on two levels: individual and collective. At the individual level, rights holders can seek redress for violations of their rights and obtain a court decision that includes measures of restitution, compensation ${ }^{18}$ and rehabilitation ${ }^{19}$. At the collective level, an effective litigation strategy reinforces the principle of equality and contributes to the public perception of no impunity in cases of women rights violations (Gauri and Gloppen, 2012, 16). In such a context, this section delves into two legal cases, one framed in the Inter-American Commission on Human Rights and the other in the CEDAW, to better understand the role of litigation in achieving SDG 2.

\subsubsection{Case Study 1: $X$ and $Y$ v. Georgia (settled by CEDAW, 2015)}

In this case, $X$ (mother) and $Y$ (daughter) claimed that Georgia failed to prevent, investigate and punish the physical, sexual and psychological abuse that for years they suffered at the hands of her husband (of $X$ ) and father (of $Y)^{20}$. Although $X$ and $Y$ complained several times to the local authorities (police and prosecutor) about the breaches to their integrity, no criminal case was filed against the aggressor (CEDAW, par. 3.1 and par. 3.2.).

In the consideration of the merits, the Committee recalled that gender discrimination encompasses gender-based violence against women (CEDAW, par. 9.3). Furthermore, it noted: (a) the careless manner in which national authorities handled $X$ and $Y$ 's complaints (CEDAW, par. 9.5), and (b) the absence - at the time of the events - of a legal framework that provides effective protection against domestic violence (CEDAW, par.9.4). Based on these considerations, the Committee declared that Georgia had failed to meet its conventional obligations to enact appropriate legislation prohibiting all discrimination against women and to ensure effective protection of women against any act of discrimination (CEDAW, par. 10). 
This case shows how the specific mechanisms of HRBA, in general, and litigation in particular, can help to tackle gender discrimination. First, this case demonstrates that successful litigation requires the existence of NGOs/civil society organizations dedicated to the advancement of women's rights. Indeed, $X$ and $Y$ were represented throughout the litigation process by Interights, the European Human Rights Advocacy Centre (EHRAC), and Article 42 (Centre for women, peace, and security, 2016), all of which are civil society organizations that specialize in strategic litigation in situations where domestic mechanisms have failed or are unavailable.

Second, this case demonstrates the efficacy of framing gender equality within a dualistic framework that has a tighter grip on the State's accountability. Thus, the Committee recommended that Georgia carried out individual and collective reparations. At the individual level, it ordered the Government to pay $X$ and $Y$ adequate financial compensation in proportion to the gravity of the violation of their rights (CEDAW, par. 11). At the collective level, the Committee recommended that Georgia: (a) ensures that domestic violence's victims have access to adequate support (shelter and psychological support); (b) introduces a zerotolerance policy in respect of violence against women, (c) ratifies the Istanbul Convention, and (d) provides mandatory training for lawyers, prosecutors and judges on domestic violence and gender stereotypes (CEDAW, par. 11).

Georgia took these recommendations seriously and, following the decision in 2015, the Ministry of Justice submitted a package of measures aimed at the ratification of the Istanbul Convention (Centre for women, peace and security, 2016). This process was completed in May 2017 with the ratification of the Istanbul Convention, which means that Georgian women now have greater protection against domestic violence (UNWOMEN, 2017). Furthermore, according to the European Human Rights Advocacy Centre, domestic violence legislation has been amended in accordance with the guidelines established in the CEDAW decision, and the government intends to open new survival shelters (European Human Rights Advocacy Centre, 2015).

\subsubsection{Case Study 2: Maria Da Penha Maia Fernandes v. Brazil (settled by the Inter-American Commission on Human Rights, 2001)}

In this case, Maria Da Penha Maia Fernandes claimed that Brazil had long tolerated her exhusband's domestic violence, which culminated in a murder attempt and additional aggression in 1983 (CIDH, par.8). Even though a criminal case was pursued against her husband in 1984 , the case remained open after 17 years. The State, in her view, had failed to meet its obligation to protect women from domestic violence and to provide effective remedies and judicial protection in a reasonable time ( $\mathrm{CIDH}$, par.23).

In the consideration of the merits, the Inter-American Commission on Human Rights stated that Brazilian judicial authorities acted with unjustified delay in a case that required immediate access to judicial remedies as well as the prosecution and conviction of the perpetrator (CIDH, par.44). Furthermore, the Commission stated that this was not an isolated case, but rather that there was a pattern throughout the entire judicial system of condoning cases of domestic violence (CIDH, par.50). Based on these considerations, the Commission declared that Brazil had failed to apply due diligence to prevent, investigate and impose penalties for the domestic violence suffered by Maria Da Penha (CIDH, par.60).

Like in $X$ and $Y$ v. Georgia, this case shows how a HRBA and litigation can help to overcome gender discrimination and achieve SDG 5. The first point to emphasize is the critical role played by civil society organizations in successful strategic litigation. In this case, the personal efforts of Maria Da Penha were support by the Center for Justice and International Law (CEJIL) and the Latin American and Caribbean Committee for the Defense of Women's Rights (Center for Justice and International Law, 2001). These institutions besides giving legal support 
during the process, together with the Commission itself, are still in charge of monitoring and implementing the final decision.

Second, this case shows the usefulness of framing gender discrimination in a logic of State's obligations. The Commission was able to determine a violation of conventional obligations and recommend appropriate reparation measures. Thus, the Commission suggested remedies at the individual and collective levels. At the individual level, it recommended that Brazil complete the criminal proceedings against the aggressor and compensate the victim both symbolically and financially for its failure to provide prompt and effective remedies (CIDH, par. 61.3). Collectively, it suggested that Brazil continue the legislative reform aimed at ending the State's condoning of domestic violence against women $(\mathrm{CIDH}$, par. 60.4).

Following these recommendations, in 2002, the aggressor was sent to jail although he only served two of a six years sentence (Center for Justice and International Law, 2001). Moreover, in 2006 Brazil promulgated Law 11340 that imposes criminal sanctions on the perpetrators of domestic violence, creates specialized policies bodies and tribunals and promotes programs of rehabilitation (BBC News, 2016). These legislative changes were precipitated by the Commission's decision.

\subsection{Conclusion}

Gender discrimination is a pervasive reality that shapes the present and future of girls and women. A HRBA helps to legitimate women's claims to equality and offers guidance to governmental and non-governmental actors in the design and implementation of pro equality programs and interventions. However, the use of legal remedies, although successful in some cases, is not accessible to all due to financial and time constrains.

\section{Conclusions}

The purpose of this paper was to explore how HRBA could contribute to the achievement of SDGs 2 and SDG 5. To do so, it first outlined the main features and core principles of HRBA before delving into its strengths and weaknesses for advancing development goals. Later, it examined the potential role of HRBA in achieving SDG 2: a world free of hunger and malnutrition and SDG 5: gender equality.

Three are the main takeaways. To begin, HRBA to development has transformed the foundations of international cooperation and aid by establishing a common methodological and theoretical framework that focuses on the claims and needs of the rights-holders rather than on donors or governmental demands. However, its effective implementation depends on strong democratic institutions, open participation processes and an effective judicial system. These structural conditions are not addressed directly by HRBA. It appears that HRBA is an excellent tool for clarifying goals, but the path to these goals necessitates the use of other approaches and tools.

Second, HRBA allows the development of clear guidelines for the implementation of SDG 2. It encourages a holistic approach to achieving SDG 2's targets, demands the participation of those who suffer food insecurity in all stages of programming, and frames food security policies as part of the State's international human rights obligations. However, not all of the SDG 2 targets may benefit from an adversarial structure of duty-bearers/rights holders; therefore, approaches that allow collaboration and cooperation among actors with diverse food interests and cosmovision need to be included.

Third, HRBA can also contribute to overcome gender discrimination and achieve gender equality. It acknowledges women's contributions in private and public domains and encourages women and their organizations to participate in decision-making processes, particularly those that directly 
affect their lives. It also promotes the State's engagement in gender equality measures by offering a clear normative and theoretical framework that outlines States' obligations regarding women's right to non-discrimination. It also provides reporting and monitoring mechanisms to ensure the implementation of women's rights following international standards. Finally, international litigation can provide victims with individual remedies while also promoting structural changes in legislation and policy regarding gender discrimination in general and domestic violence in particular.

1 The Human Rights-Based Approach to Development Cooperation: Towards a Common Understanding Among UN Agencies (2003). URL:https://unsdg.un.org/resources/human-rights-based-approachdevelopment-cooperation-towards-common-understanding-among-un

2 Following this reasoning, development cooperation is not grounded in charity but legitimate rights of the globally or locally disadvantages.

3 In this section, I do not consider the principle of universality because its operational consequences overlap with already discussed concepts.

4 UN Charter. Art. 55-57.

5 Mainly public participation, non-discrimination and due process.

6 As Margret Vidar $(2005,141)$ points out, the reality of hunger and malnutrition involves other rights such as the right to health, the right to education and the right to work.

9 Subsequently, it was reaffirmed at the World Food Summit organized by the Food and Agriculture Organization of the United Nations (FAO) in 1996 and the Millennium Declaration adopted by the United Nations in 2000.

10 See:https://www.gob.pe/institucion/qaliwarma/pages/591-programa-de-alimentacion-escolar-qali warma. Accessed: 15.06.2021.

11 Adopted by the United Nations General Assembly on 18 December 1979.

13 This compromise was reaffirmed by the Programme of Action of the International Conference on Population and Development and the Beijing Platform for Action.

14 Due to limited space, I do not delve into other mechanisms of protection such as the ones established based on the UN Charter, such as the Special Rapporteur on Violence against Women and the Working Group on the issue of discrimination against women in law and practice.

15 Maputo Protocol" adopted 11 July 2003.

16 "Convention of Belem do Para" adopted 6 September 1994

17 "Istanbul Convention" adopted 11 May 2011.

18 Whether provided in the form of money, goods or services.

19 Medical and psychological care and other social services.

20 Articles 1, 2 (b)- 2(f) and 5(a) of the Convention. 


\section{References}

Broberg, M. and H. Sano (2017). "Strengths and weaknesses in a human rights-based approach to international development- an analysis of a rights-based approach to development assistance based on practical experiences". The International Journal of Human Rights. Routledge.

Bull, B. (2006). Development theory revisited. In: Banik, D. Poverty, politics and development. Interdisciplinary Perspectives. Fagbokforlaget.

Epp, C. (1998). The Rights Revolution. Lawyers, Activists, and Supreme Courts in Comparative Perspective. Chicago and London: The University of Chicago Press.

Goonesekere, S. (2009) "Civil and Political Rights and Poverty Eradication". In VAN VUEREN, G. Freedom from Poverty as a Human Right: "Law's Duty to the Poor". Paris: UNESCO.

Goonesekere, S. (1998, October). A rights-based approach to realizing gender equality. In Keynote speech at the Seminar on a Rights-Based Approach to Gender Equality, Rome (pp. 5-7).

Goonesekere, S. W. (2007). The concept of substantive equality and gender justice in South Asia. Unpublished Paper.

Gauri, V., and Gloppen, S. (2012). Human rights-based approaches to development: Concepts, evidence, and policy. Polity, 44(4), 485-503.

Jonsson, U. (2005). A human rights-based approach to programming. Reinventing development, 47-62.

Jetschke, A., and Liese, A. (2013). The power of human rights a decade after. In T. Risse, S. Ropp, \& K. Sikkink (Eds.), The Persistent Power of Human Rights: From Commitment to Compliance (Cambridge Studies in International Relations, pp. 26-42). Cambridge: Cambridge University Press.

Kirkemann, J. and H. Sano. The implications and value added of a human rights-based approach. In: Marks, Stephen and Andreassen (eds.). Development as a Human Right. Legal, Political and Economic Dimensions. Intersentia.

Sano, H. (2007). Does Human Rights-based Development Make a Difference? In: Vandenhole, Tostensen and Salomon. Casting the Net Wider. Human Rights, Development and New Duty-bearers. Intersentia.

Risse, T., S. Ropp, And K. Sikkink (editors) (2013). The Persistent Power of Human Rights. From Commitment to Compliance. Cambridge: Cambridge University Press.

Sengupta, A. (2010). The Human Right to Development. In: Marks, Stephen and Andreassen (eds.). Development as a Human Right. Legal, Political and Economic Dimensions. Intersentia.

Amartya, S. (1999). Development as Freedom. Oxford University Press.

Gonsalves, C. (2005). From international to domestic Law: The case of the Indian Supreme Court in response to ESC Rights and the right to food. In: Wenche Barth Eide and Uwe Kracht (eds.). Food and Human Rights in Development. Volume II. Intersentia.

Vidar, M. (2005). The interrelationships between the right to food and other human rights. In: Wenche Barth Eide and Uwe Kracht (eds.). Food and Human Rights in Development. Volume I. Intersentia 
UN Documents:

United Nations Development Group (2003). The Human Rights Based Approach to Development Cooperation: Towards a Common Understanding Among UN Agencies. https://unsdg.un.org/resources/ human-rights-based-approach-development-cooperation-towards-common-understandingamong-un. Accessed: 18.06.2021.

UN General Assembly (2015). UN.Doc.A/RES/70/1. Transforming our world: the 2030 Agenda for Sustainable Development. https://www.un.org/en/development/desa/population/migration/ generalassembly/docs/globalcompact/A_RES_70_1_E.pdf. Accessed: 15.06.2021.

Office of the United Nations High Commissioner for Human Rights (2008). Frequently Asked Questions on a Human Rights-Based Approach to Development Cooperation. http://www.ohchr.org/ Documents/Publications/FAQen.pdf. Accessed: 10.06.2021.

Committee on Economic, Social and Cultural Rights (1999). UN.Doc.E/C.12/1999/5. General Comment No. 12: The Right to Adequate Food (Art. 11). https://www.refworld.org/pdfid/4538838c11. pdf. Accessed: 10.06.2021.

Committee on the Elimination of Discrimination against Women (2015). UN.Doc.CEDAW/C/GC/33. General Recommendation 28 on women's access to justice. https://tbinternet.ohchr.org/Treaties/ CEDAW/Shared\%20Documents/1_Global/CEDAW_C_GC_33_7767_E.pdf. Accessed: 10.06.2021.

Committee on the Elimination of Discrimination against Women (2010). UN.Doc.CEDAW/C/GC/28. General recommendation No. 28 on the core obligations of States parties under article 2 of the Convention on the Elimination of All Forms of Discrimination against Women. https://www. refworld.org/docid/4d467ea72.html. Accessed: 10.06.2021.

Committee on the Elimination of Discrimination against Women (2015). UN.Doc.CEDAW/C/61/D/24/2009. Communication No. 24/2009. https://undocs.org/en/CEDAW/C/61/D/24/2009. Accessed: 10.06.2021.

Food and Agricultural Organization of the United Nations (2017). The state of food security and nutrition 2017. http://www.fao.org/state-of-food-security-nutrition/en/. Accessed: 10.06.2021.

Special Rapporteur on the Right to Food (2013). UN.Doc.A/68/288. Report to the General Assembly. Assessing a decade of progress on the right to food. https://undocs.org/A/68/288. Accessed: 05.06.2021.

Special Rapporteur on the Right to Food (2006). UN.Doc.E/CN.4/2006/44. Report to the Commission on Human Rights. Defining the right to food in an era of globalization. https://undocs.org/E/ CN.4/2006/44. Accessed: 07.06.2021.

Special Rapporteur on the Right to Food (2012). UN.Doc.A/HRC/19/59/Add.2. Report to the Human Rights Council. Mission to Mexico. https://undocs.org/A/HRC/19/59/Add.2. Accessed: 10.06.2021.

UNWOMEN (2017). Women and Sustainable Development Goals. SDG 5: Achieve gender equality and empower all women and girls. https://www.unwomen.org/en/news/in-focus/women-and-thesdgs/sdg-5-gender-equality. Accessed: 13.06.2021.

Normative:

Universal Declaration on Human Rights. 10.06.1948.

United Nations Charter. 26.06.1945.

Convention on the Elimination of All Forms of Discrimination Against Women. 18.12.1979. 
The Protocol to the African Charter on Human and Peoples' Rights on the Rights of Women in Africa. 11.07.2003.

The Inter-American Convention on the Prevention, Punishment, and Eradication of Violence against Women. 09.06.1994.

The Council of Europe Convention on preventing and combating violence against women and domestic violence. 11.05.2011.

Other sources:

European Coordination Via Campesina (2018). Food Soverignity NOW! https://viacampesina.org/en/wpcontent/uploads/sites/2/2018/02/Food-Sovereignty-A-guide- Low-Res-Vresion.pdf. Accessed: 15.06.2021.

UNWOMEN. Georgia ratifies the Istanbul Convention. http://eca.unwomen.org/en/news/stories/2017/05/ georgia-ratifies-the-istanbul-convention. Accessed: 15.06.2021.

European Human Rights Advocacy Centre (2015). Landmark cases. X and Y v. Georgia. https://ehrac.org. uk/resources/cedaw-decision-X-and-y-v-georgia/. Accessed: 16.06.2021.

BBC News (2016). The woman who changed Brazil's domestic violence laws. http://www.bbc.com/news/ magazine-37429051. Accessed: 05.06.2021.

Center for Justice and International Law (CEJIL). Landmark cases. Maria Da Penha Maia Fernandes v. Brazil. https://cejil.org/en/case/maria-da-penha-4/. Accessed: 22.06.2021.

Centre for women, peace and security (2016). Landmark cases. X and Y v. Georgia. https://blogs.lse.ac.uk/ vaw/landmark-cases/a-z-of-cases/X-and-y-v-georgia/. Accessed: 09.06.2021.

Centre for women, peace and security (2016). Landmark cases. Maria Da Penha Maia Fernandes v. Brazil. https://blogs.Ise.ac.uk/vaw/landmark-cases/a-z-of-cases/maria-de-penha-v-brazil/. Accessed: 14.06.2018.

Inter-American Commission on Human Rights. Maria da Penha v. Brazil, Case 12.051, Report No. 54/01, OEA/Ser.L/N/II.111 Doc. 20 rev. at 704 (2000). http://hrlibrary.umn.edu/cases/54-01.html. Accessed: 14.06.2018. 